\title{
Analyzing of the Factors Affecting the Exposure of Adolescents to Peer Bullying
}

Müfide Çalık ${ }^{1}$

\begin{tabular}{l} 
ART ICLE INFO \\
\hline Article History: \\
Received 02.01.2020 \\
Received in revised form \\
31.07 .2020 \\
Accepted \\
Available online \\
01.07 .2021
\end{tabular}

\begin{abstract}
This study was prepared to examine the factors affecting peer bullying exposure considering adolescents' gender, age and classes. The study area of the research was applied to 9 th and 10 th grade students of Sakarya province Sapanca Vocational and Technical Anotolian High School. In this study, 10 students were asked questions to examine the factors affecting adolescent's exposure to peer bullying. Students' responses were evaluated using the interview form. Although the problems of adolescence differ in the historical process, they have existed in all societies until today. Because adolescents experience self-fornation in this process, plan the future and go through a very difficult process. The importance of friendship, popularity, self-realisation,setting goals and most importantly,rapid biological,psychological and social changes can attract these individuals in different problems. Thus, adolescents' reactions to these problems sometimes go to extremes and increases in violence are observed. Bullying, which is a form of aggression, is used for purposes such as achieving one's own goals, establishing authority, and making somebody give up. The increase of aggression events in the world and in our country in recent years has also increased the studies on this issues. In this study, the relationship between peer bullying and some factors such as age ,gender, physical characteristics, personality traits and parental attitudes affecting peer bullying were investigated.
\end{abstract}

CTUARA Journal. All rights reserved

Keywords:

Adolescents, victim, exposure

$\begin{array}{ll} & \text { Keywords: } \\ \text { Adolescents, victim, exposure }\end{array}$

\section{INTRODUCTION}

Peer bullying- a form of aggression- is defined as negative behaviors involving pysical, verbal, psychological assault or forcing the person who has physical or psychological power inequality to give up knowingly and willingly, aiming to cause fear or anxiety in the victim (Olweus ,1993). The violence observed in schools in our country is increasing and measures taken do not go beyond discipline rules. Students who have fought in the primary and high school periods and damaged school materials have been encountered until now. However, recent violence in different types has reached the level which will worry almost all of the society in addition to parents and educators. We see that the violence seen in schools affects the quality of life and success level of the student. Based on this situation, this research was carried out to determine adolescents' encountering of violence and perception of violence and factors affecting it.

Peer bullying, is when one person behaves regularly or intermittently to another person negatively, or acts in malicious and repetitive physical and verbal behavior that may lead to psychological distress (Bridge,2003). The occurrence of bullying behavior can ocur at least two people who are bullying and bullied. However, most researchers state that bullying has a more complex structure and there are different forms of bullying. Different forms of being bully are also generally called bullying statuses. These statuses are bully, victim, bully-victim, non-interference or spectators. People who constantly attack individuals - less powerful than herself- with the aim of harming are called bully; people who are bullied are called victim.

According to Berker (2007), there are three important points in recognizing peer bullying

1. It does not occur as a result of any provocation.

2. It repeats over time.

3. The child who exhibits peer bullying is stronger than the child in focus, or more powerful.

According to Deveci's research (2002), there are some differences between girls and boys in terms of exposure and types of peer bullying behaviors. That is, while boys are exposed to physical or direct attacks such as open attacks, girls are exposed to more relational or indirect attacks. Similarly, relational aggression unlike explicit aggression is mostly applied by girls; physical attacks often occurs among boys. 
The subject of conflict is anthropology, sociology, psychology, economy today. and one of the issues that management sciences intensively examine It comes. Since the phenomenon of conflict has been studied by scientists from different perspectives it is difficult to find a common definition in this regard (Eroğlu, 1992). When all of these are evaluated together, it is understood that violence will have a significant social, economic, emotional and spiritual burden to the individual, family and society and it will be inevitable to transfer from generation to generation unless it is prevented. At the same time, the continuing spread of violence transferred from generation to generation will prevent the future of the society from being based on solid foundations by causing various health problems and disruptions in the social structure of the society. In this sense, the adolescent needs to maintain positive psychosocial development by establishing positive social relationships in order not to have behaviors that are harmful to health (Özgür, Yörükoğlu \& Baysan, 20119). Besag (1995:4) defines bullying as "physical, psychological, social or verbal repetitive attack of a strong person or people in order to distress those who are not opposed to stand up for their own interests or wishes" (Çağırgan, 2014). Mynard and Joseph described peer bullying in four dimensions. Three of those dimensions are physical, verbal and relational aggression -as mentioned earlier-, the fourth one is identified as attack on personal belongings. Attack on personal belongings includes "behaviors such as damaging the target person's belongings, taking them without permission, stealing" (Çağırgan, 2014).

Austin and Joseph (1996) divides peer bullying into two as physical aggression dimension; involving physical contact such as kicking, hair pulling and verbal aggression dimension; involving verbal assaults, mocks and insults to the victim. The definition of violence in detail was made by the World Health Organization. Violence is an individual's use of threats or physical force, which can result in injury, death, physical harm, some developmental disorders or withdrawal towards herself, someone else, to a particular community or group (World Health Organization ,2002). Arslan and Yeşilyurt (2019) found that adolescents' scores from the cyber bullying scale were significantly different from those of families with high income levels and families with middle income.Yavuzer (2006: 111) states that "adolescence between the ages of 11-20 is a search process in which personality gains social quality". Adolescence is one of the most important processes of human development. "The time of adolescence increases with adolescents during adolescence and they are more influenced by their friends than in childhood." (Kulaksızoğlu, 2005:86). The feedback from the friends is reflected in the adolescent's communication with other people. In adolescence, adolescent relations can be destructive as well as constructive (Çağırgan, 2014).

\section{Situation of the Problem}

Peers considering adolescents' gender, age and classes What are the factors affecting bullying exposure?

The aim of the research is to take the opinions of adolescents on the examination of the factors affecting peer bullying exposure by considering the gender, age and the classes they study.

\section{METHOD}

In this study, "a semi-structured interview technique was used. This technique is defined as (Yıldırım \& Şimşek, 2008) the research in which qualitative data collection methods such as observation, interview, document analysis are used, and where a qualitative process is pursued to reveal perceptions and events in a realistic and holistic way"

In the research, the interview form developed to examine the factors affecting the adolescent's exposure to peer bullying was finalized in line with expert opinions. The interview form includes seven open-ended questions.

\section{Study Group}

In this study, the study group was determined by an easily accessible sampling method. In this method, the researcher chooses a situation that is close and easily accessible and adds speed and practicality to the research (Yıldırım \& Şimşek, 2008).

10 students studying at the Sapanca Vocational and Technical Anatolian High School, located in the district of Sakarya, Sapanca, constitute the working group of the research. All of the students forming the study group are men. The average age of students is 15.6. 


\section{Data Collection Tool}

In this study, interview forms were used as data collection tool. During the preparation phase of the interview questions, 7 open-ended questions that would best express the relevant sub-problems were prepared and written on the interview form. Open-ended research questions "provide the researcher with an flexible and open-ended approach to the subject that he wants to examine" (Yıldırım \& Şimşek, 2008).

The interviews were held on the dates and times determined according to the students' school hours. The interviews were written and recorded on the computer in order to avoid loss of data. During the interview, the students answered all 7 questions expressed and said their opinions.

\section{Data Analyses}

The data gained from the interviews were analyzed by descriptive analysis method. Descriptive analysis consists of four stages as creating a framework for descriptive analysis, processing data according to the thematic framework, defining findings and interpreting the findings (Yıldırım \& Şimşek, 2008).

The thematic framework was determined by the researchers for the analysis of the data. In this context, the data were first coded by each researcher. Then, common coding was made in common themes with the researchers' common views by comparing the data gathered.

The written texts formed as a result of the interviews were examined again and again, the data suitable for the purpose of the research were coded, and the themes, explaining the coded data at a general level, were determined.

The findings are arranged in tables. The interviewed students are coded starting from S1 to S10. In the interpretation of the findings, direct quotations from the views of the teachers were included.

\section{FINDINGS}

In this section, the findings obtained from the research are included.

The opinions of adolescents who are exposed to peer bullying about the factors affecting their situation are shown in tables below.

Adolescents' views on peer bullying are presented in Table 1.

Table 1. Adolescents' views on peer bullying

\begin{tabular}{llll}
\hline \multicolumn{1}{c}{ Theme (Categories) } & \multicolumn{1}{c}{ Codes } & $n$ & $\%$ \\
\hline & Physical violence (S2,S3,S4,S5,S7,S9) & 6 & 60 \\
& Asking for money (S4,S7) & 2 & 20 \\
& Don't swear (S5,S6) & 2 & 20 \\
& Don't threaten (S6,S8) & 2 & 20 \\
Encounter peer bullying & Kidding (S8,S10) & 2 & 20 \\
& Unconscious behavior (S1) & 1 & 10 \\
& Irresponsible action (S1) & 1 & 10 \\
& Humiliation (S10) & 1 & 10 \\
\hline
\end{tabular}

When Table 1 is examined, it is seen that the opinions of adolescents regarding peer bullying are $60 \%$ of physical violence. Other opinions are as follow: $20 \%$ asking for money, don't swear, don't threaten and kidding, $10 \%$ unconscious behavior, irresponsible action and humiliation . The exact quotations taken from the opinions of the students are presented below.

"I faced bullying in the form of slapping using her physical strength."(S2) "We had a fight with my friend."(S3)

"Don't hit my head, asking for money using physical violence."(S4) "I faced bullying in the form of swearing and tattooing, hitting."(S5)

The opinions of adolescents about how they feel when they are bullied are presented in Table 2 .

Table 2. Adolescents' views on how they feel when they are bullied by their peers 


\begin{tabular}{|c|c|c|c|}
\hline Theme (Categories) & Codes & $n$ & $\%$ \\
\hline \multirow{7}{*}{$\begin{array}{c}\text { How she felt when she } \\
\text { was bullied by } \\
\text { her/his peer }\end{array}$} & Upset $(\mathrm{S} 1, \mathrm{~S} 6, \mathrm{~S} 9, \mathrm{~S} 10)$ & 4 & 40 \\
\hline & Angry (S3,S4,S5,S7) & 4 & 40 \\
\hline & Alone (S6,S8,S10) & 3 & 30 \\
\hline & Helpless (S3,S6,S7) & 3 & 30 \\
\hline & Vulnerable $(\mathrm{S} 2, \mathrm{~S} 7, \mathrm{~S} 9)$ & 3 & 30 \\
\hline & Frightened $(\mathrm{S} 3, \mathrm{~S} 4, \mathrm{~S} 7)$ & 3 & 30 \\
\hline & Excluded $(S 8, S 10)$ & 2 & 20 \\
\hline
\end{tabular}

When Table 2 is examined, it is seen that the views of adolescents about what they feel when they are bullied by peers are mostly up to $40 \%$ upset and angry. Other opinions are as follow: $30 \%$ alone, helpless, vulnerable and frightened and $20 \%$ excluded. The exact quotations taken from the opinions of the students are presented below.

"I tried to respond first, I tried not to worry, but then I was sad and very angry."(S1) "I felt lonely and helpless."(S6) "I was powerless and defenseless."(S9) "I got angry and wanted to attack, but I was afraid."(S4)

The opinions of adolescents about how they behave when faced with peer bullying are presented in Table 3. Table 3. Adolescents' views on how they behave when faced with peer bullying

\begin{tabular}{|c|c|c|c|}
\hline Theme (Categories) & Codes & $n$ & $\%$ \\
\hline \multirow{6}{*}{$\begin{array}{c}\text { Behavior in case of } \\
\text { bullying }\end{array}$} & Fear $(\mathrm{S} 4, \mathrm{~S} 5, \mathrm{~S} 6, \mathrm{~S} 7)$ & 4 & 40 \\
\hline & Getting help from the family $(\mathrm{S} 4, \mathrm{~S} 9, \mathrm{~S} 10)$ & 3 & 30 \\
\hline & Shut up $(\mathrm{S} 6, \mathrm{~S} 7)$ & 2 & 20 \\
\hline & Warn $(\mathrm{S} 1, \mathrm{~S} 10)$ & 2 & 20 \\
\hline & Have a grudge (S3) & 1 & 10 \\
\hline & Not to respond (S8) & 1 & 10 \\
\hline
\end{tabular}

When Table 3 is examined, it is seen that the opinions of adolescents about how they behave when they encounter peer bullying are $40 \%$ most "fear". Other opinions are as follow: $30 \%$ getting help from the family, $20 \%$ shut up and warn, $10 \%$ have a grudge and not to respond. The exact quotations taken from the opinions of the students are presented below.

"At first I could not say anything to anyone because I was afraid, I tried to calm down, but then I asked my family for help."(S4)

"I tried to be calm because I'm scared."(S5) "I was silent and I can't speak to anyone with fear."(S6) "I was silent because I was scared."(S7)

The opinions of adolescents about sharing peer bullying with someone is presented in Table 4 .

Table 4. Adolescents' views about sharing peer bullying with someone

\begin{tabular}{clcc}
\hline \multicolumn{1}{c}{ Theme (Categories) } & \multicolumn{1}{c}{ Codes } & $n$ & $\%$ \\
\hline \multirow{3}{*}{ Sharing peer bullying } & No (S1,S3,S5,S6,S7,S8) & 6 & 60 \\
& I shared it with my family $(\mathrm{S} 4, \mathrm{~S} 9, \mathrm{~S} 10)$ & 3 & 30 \\
& Yes (S2) & 1 & 10
\end{tabular}

When Table 4 is analyzed, it was seen that the opinions of adolescents about sharing peer bullying with someone was $60 \%$ "no" at most. Other opinions are as follow: $30 \%$ I shared it with my family and 10\% yes. The exact quotations taken from the opinions of the students are presented below.

"No, I did not need to share."(S1) "No, I did not share it with anyone."(S3) 
The views of adolescents about how to deal with peer bullying are presented in Table 5 .

Table 5. Adolescents' views on how to deal with peer bullying

\begin{tabular}{llll}
\hline \multicolumn{1}{c}{ Theme (Categories) } & \multicolumn{1}{c}{ Codes } & $n$ & \% \\
\hline \multirow{3}{*}{ Coping with bullying } & With help (S1,S2,S5,S7,S9,S10) & 6 & 60 \\
& No, I do not know (S4,S6,S8) & 3 & 30 \\
& Strongly (S3) & 1 & 10
\end{tabular}

When Table 5 is analyzed, it is seen that adolescents' views on how to deal with peer bullying are mostly with the help of $60 \%$. Other opinions are as follow: $30 \%$ no, I do not know and 10\% strongly. The exact quotations taken from the opinions of the students are presented below.

"I get help from my elders."(S9)" No, I do not know." (S4) "I fight."(S7)

The opinions of adolescents regarding the question "What did you feel about the bully?" Are presented in Table 6.

Table 6. "How did you feel about the person who bullied you?" views on the question

\begin{tabular}{clcc}
\hline Theme (Categories) & & Codes & $\boldsymbol{n}$ \\
\hline \multirow{2}{*}{$\begin{array}{c}\text { How did you feel about } \\
\text { the person who bullied }\end{array}$} & Angry (S3,S4,S8,S9) & 4 & 40 \\
you? & Stressful (S1,S4) & 30 & 3 \\
& Upset (S1) & 20 & 10
\end{tabular}

When Table 6 is examined, it is observed that the views of adolescents about the question "What did you feel about the person who bullied you?" Were at most 40\% angry. Other opinions are as follow: 30\% hate, 20\% stressful and $10 \%$ upset. The exact quotations taken from the opinions of the students are presented below.

"I feel hatred and hatred."(S2)

"I feel very stressed."(S4)

"I am so sorry."(S1)

The views of adolescents about the question "How did they approach you when you shared peer bullying with your family?" are presented in Table 7.

Table 7. "How did they approach you when you shared your peer bullying with your family? "Views on the question

\begin{tabular}{|c|c|c|c|}
\hline Theme (Categories) & Codes & $n$ & $\%$ \\
\hline \multirow{3}{*}{$\begin{array}{l}\text { Family approach in case } \\
\text { of bullying }\end{array}$} & I couldn't tell my family $(\mathrm{S} 1, \mathrm{~S} 3, \mathrm{~S} 5, \mathrm{~S} 6, \mathrm{~S} 7, \mathrm{~S} 8)$ & 6 & 60 \\
\hline & They supported (S2,S4,S9) & 3 & 30 \\
\hline & They do not care (S10) & 1 & 10 \\
\hline
\end{tabular}

When Table 7 is analyzed, the adolescents say, "How did they approach you when you shared peer bullying with your family?" It was seen that his views on the question were mostly not to tell my family. Other opinions are as follow: 30\% they supported and 10\% they do not care. The exact quotations taken from the opinions of the students are presented below.

"I couldn't tell my family."( S3)

"My family supported this."(S4)

"When my sister said, she never cared."(S10)

\section{Result and Discussion}

The results obtained in the research conducted to determine the opinions of adolescents about the factors affecting peer bullying are presented below.

The results obtained in the research conducted to determine the views of adolescents about the factors affecting peer bullying can be summarized as follows:

1.Adolescents' views on what kind of peer bullying are $60 \%$ physical violence. 
2. Adolescents' views about how they feel when they are bullied by their peers have been upset by $40 \%$ and I got upset by $40 \%$.

3. The opinions of the adolescents about how they behaved in the face of peer bullying were $40 \%$ afraid.

4. The opinions of adolescents about sharing peer bullying with one of them were $60 \%$ no.

5. The opinions of adolescents about how to deal with peer bullying have been in the form of $60 \%$ help.

6. The views of adolescents about how they feel towards the bully was $40 \%$ angry.

7. When they shared the situation of adolescent peer bullying with their families, their opinions about how the families approached were $60 \%$.

According to the results of the research, the finding is that men are exposed to bullying more through physical or direct attacks. Accordingly, in our study, it is possible to say that men in the first and middle adolescence, by exerting physical and verbal power and threats to their peers, they digest them and damage their private belongings. This gender-specific achievement, which boys see as fighting as an opportunity to prove their strength and courage to others (Rauste-von Wright, 1989), and the tendency to prefer direct confrontation with others (Arslan, 2017;Cairns, Cairns, Neckermann and Gariepy, 1989) there may be an explanation for the trend. Similarly, in the physical, relational and ridicule subtypes of bullying, it has been reported that there is an increase in transition to 9 classes in adolescence, and this situation is associated with the highest status in school (Bayraktar, 2009). In the research, the most important part of adolescents' preferences in coping with bullying was to apply brute force to bullying. In other studies, the preference is to stay away from bullying. Some researchers consider avoiding bullies as a strategy of approaching the problem in dealing with stress and combating bullying (Alkan\& Arslan,2020;Kristensen \& Smith, 2003). it can be said that adolescents reported preferences to prevent the problem from continuing in the first place. Then, respectively, adolescents reported preferences for solving problems such as asking them to stop and seeking social support such as telling someone. The finding in this direction largely overlaps with some other research findings (Yesilyurt,Arslan \& Arslan,2021;Kristensen \& Smith, 2003). Suggestions

1.It is recommended that adolescents' families be slightly more interested in their children. Thus, children can express their bullying situation more easily.

2. Teachers can be provided to receive seminars on how to treat an adolescent who is peer bullied.

3. Seminars on peer relationships and peer bullying are offered to adolescents to inform them about how they should behave in the event of facing peer bullying and how to deal with peer bullying.

4. In schools, boards should be prepared by the guidance service and information posters should be hung.

\section{References}

Arslan,S. \& Yesilyurt,F. (2019). Ergenlerin Sanal zorbalık düzeylerinin bazı değişkenler açısından incelenmesi. OPUS-Uluslararası Toplum Araştırmaları Dergisi,11(18),27-42.

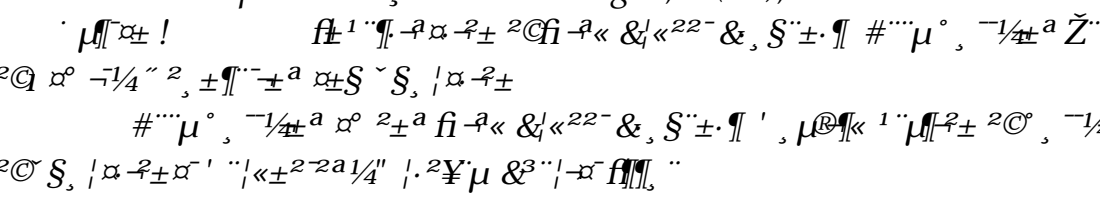

Baldry, A. C. \& Farrington, D. P. (1999). Types of bullying among italian school children. Journal of Adolesence, 22, 423-426.

Bayraktar, F. (2009). Ergenlerin zorba ve kurban davranışlarında birey, aile, akran ve okula dair özelliklerin rolü: Bütüncül bir model önerisi. Yayınlanmamış doktora tezi. Hacettepe Üniversitesi, Ankara

Budak, S. (2003). Psikoloji sözlüğ̈̈. 2. baskı. Ankara: Bilim ve Sanat Yayınları.

Bulut, S. (2008). Okullarda görülen öğrenciden öğrenciye yönelik şiddet olaylarının bazı değişkenler açısından arşiv araştırma yöntemiyle incelenmesi. Abant İzzet Baysal Üniversitesi Eğitim Fakültesi Dergisi 8:23-38. 
Burnukara P. \& Uçanok Z.(2012). İlk ve orta ergenlikte akran zorbalığ gerçekleştiği yerler ve baş etme yolları. Türk Psikoloji Yazıları, Haziran 2012, 15 (29), 68-82

Cairns, R. B.,Cairns, B. D., Neckermann, H. J., Fergusson, L. L. \& Gariepy, J. (1989). Grow than daggression: Child hood to early adolescense. Develop mental Psychology, 25, 320-330.

Crick, N. R. \& Grotpeter, J. K. (1995). Relationalaggression, gender, andsocial-psychologic alad justment. Child Development, 66(3), 710-722.

Eroğlu, F. (1992). "Örgüt-Çeore Etkileşimi Açısından Çatışma Yönetimi”, Yüksek lisans Tezi, Erzurum: Atatürk Üniversitesi Sosyal Bilimler Enstitüsü.

Gelbal, S. (2006). Okullarda şiddetin önlenmesi, mevcut uygulamalar ve sonuçları. Türk Eğitim Derneği Kitapçı̆̆ı. Ankara: s. 28-31.

Güney, C. (2008). Şiddetin bahanesi olmaz. Tepe Yayınları - Arı Matbaası; İstanbul:

Jörkqvist, K.,Lagerspetz, K. M. J. \& Kaukiainen, A. (1992). Do girls manipulate and boys fight? Development altrends in regard to direct and in direct aggression. Aggressi ve Behavior, 18, ll7-l27

Kristensen, S. M. \& Smith, P. K. (2003). Theuse of coping strategies by Danish children classed as bullies, victims, bully/victims, and not involved, in responseto different (hypothetical) types of bullying. Scan dinavian Journal of Psychology, 44, 479-488.

Mynard, H. \& Joseph, S. (2000). Development of the multi dimensional peer victim ization scale. Aggressi ve Behavior, 26, 169-178.

Pekel-Uludağlı, N. \& Uçanok Z. (2005). Akran zorbalığı gruplarında yalnızlık ve akademik başarı ile sosyometrik statüye göre zorba/ kurban davranış türleri. Türk Psikoloji Dergisi, 56, 77-92

Pişkin, M. (2002). Okul Zorbalığı: Tanımı, türleri, ilişkili olduğu faktörler ve alınabilecek önlemler. Uygulamada Ĕ̆itim Bilimleri. 2 (2). 531-562.

Sharp, S. \& Smith, K.P. (1994). Under standing bulling. Tadding bulling in your school. 1-6. Newyork: Routhledge.

Şirvanlı-Özen, D. (2006). Ergenlerde akran zorbalığına maruz kalmanın yaş, çocuk yetiştirme stilleri ve benlik imgesi ile ilişkisi. Türk Psikoloji Dergisi, 58, 77-94

Yesilyurt,F.,Arslan,N. \& Arslan,S. (2021). Cyber bullying and self-disclosure: The predicting role of cyber bullying. Malaysian Online Journal of Educational Technology,9(1),19-25.

World Health Organization (2002) World Report on Violence and Health. Geneva:

\section{INTERVIEW FORM}

Dear Student;

This study has been prepared for the research titled "Investigation of factors affecting peer bullying by considering the gender, age and classes in which adolescents are educated" as a master study of the Department of Education Programs and Teaching at Sakarya University Educational Sciences Institute.

The information obtained from the study will be used only for scientific purposes and will not be shared with third parties.

Gender: Age: Class:

\begin{tabular}{|c||l||}
\hline 1 & STUDENT INTERVIEW QUESTIONS \\
\hline \hline $\mathbf{1}$ & What kind of peer bullying did you encounter? \\
\hline \hline $\mathbf{2}$ & How did you feel when you were bullied by peers? \\
\hline \hline $\mathbf{4}$ & How did you act when you faced peer bullying? \\
\hline $\mathbf{5}$ & Have you shared the peer bullying you experienced? \\
\hline $\mathbf{6}$ & Do you know how to deal with peer bullying? \\
\hline \hline $\mathbf{7}$ & How did you feel about the person who bullied you? \\
\hline \hline
\end{tabular}

